Research, part of a Special Feature on Exploring Social-Ecological Resilience through the Lens of the Social Sciences: Contributions, Critical Reflections, and Constructive Debate

\title{
Understanding adaptation and transformation through indigenous practice: the case of the Guna of Panama
}

\author{
Marina J. Apgar $^{1}$, Will Allen $^{2}$, Kevin Moore $^{3}$ and James Ataria $^{4}$
}

\begin{abstract}
Resilience is emerging as a promising vehicle for improving management of social-ecological systems that can potentially lead to more sustainable arrangements between environmental and social spheres. Central to an understanding of how to support resilience is the need to understand social change and its links with adaptation and transformation. Our aim is to contribute to insights about and understanding of underlying social dynamics at play in social-ecological systems. We argue that longstanding indigenous practices provide opportunities for investigating processes of adaptation and transformation. We use in-depth analysis of adaptation and transformation through engagement in participatory action research, focusing on the role of cultural and social practices among the Guna indigenous peoples in Panama. Our findings reveal that cultural practices facilitating leadership development, personhood development, and social networking are critical for enabling both adaptation and transformation. Further, we argue that Guna ritual practice builds additional skills, such as critical self-reflection and creative innovation, that are important for supporting the deeper changes required by transformation.
\end{abstract}

Key Words: adaptation; cultural practice; Guna; reflection; resilience; ritual; participatory action research; transformation

\section{INTRODUCTION}

Challenges such as climate change (Richardson et al. 2009), high levels of environmental degradation (UNEP 2009), and peak oil consumption (Kerr 2007) all indicate that the current relationship between the social and environmental spheres is becoming unsustainable. Sustainability science is using the concept of social-ecological resilience and its associated tools and approaches to understand and influence this relationship (Folke et al. 2002, Turner 2010). As Marshall et al. (2009:904) observed, " $[\mathrm{r}]$ esilience is an important concept that is emerging to guide and support more inclusive approaches to the management of combined social and ecological systems" (following Ludwig et al. 1997, Berkes and Folke 1998). Social-ecological resilience is fundamentally about people and nature operating as interdependent systems (Berkes et al. 2000, Folke et al. 2010). This is true for local communities and their surrounding ecosystems, but it is increasingly being recognized as necessary at national, regional, and international scales.

Although the idea of resilience is now used in multiple fields, its meaning remains contested (Bahadur and Tanner 2014, Brown 2014). Common resilience concepts include capacity, connectedness, adaptation, and feedback (Brown and Westaway 2011). These concepts highlight that social change, i.e., people and institutions changing norms, behaviors, and relations, is essential for social-ecological system (SES) resilience (Folke et al. 2010). Moreover, social change within SESs is often referred to in two forms: adaptation and transformation. Adaptation recognizes the capacity of the social actors involved in an SES to learn, combine experience and knowledge, and adjust social behavior to maintain a resilient system in the face of changing internal and external forces (Berkes et al. 2003, Walker et al. 2004, Folke et al. 2010). This is also referred to by some as incremental adaptation (Kates et al. 2012, Park et al. 2012). In contrast, transformation can be seen as a larger intentional change that creates a fundamentally different system when ecological, economic, or social structures make the existing system untenable (Gunderson and Holling 2002, Walker et al. 2004, Folke et al. 2010). Distinguishing between these two levels of change and learning how to move toward more transformative change are now part of central debates and policy processes within the field of climate change adaptation (Kates et al. 2012, Preston et al. 2013, Mimura et al. 2014).

The results of these SES changes manifest in interlinked social and ecological subsystems. Consequently, deepening our understanding of good management will require closer collaboration between social and ecological disciplines. This requires us to engage with the challenges inherent in integrating the social and the ecological (Allen et al. 2014) through a better balance of research effort. For resilience in particular, Armitage et al. (2012) remind us that the ecological dimensions have been more influential in practice and better theorized than the social ones. Early work on social aspects of resilience (e.g., Adger 2010) focused mainly on the institutional and structural aspects of societies and their relationship to environmental management. Recent reviews of the human aspects of resilience highlight gaps and flaws in current thinking (Davidson 2010, Pelling and Manuel-Navarette 2011, Cote and Nightingale 2012, Brown 2014). These criticisms highlight inadequate understandings of the multiple dimensions of power and agency in SESs (Buikstra et al. 2010, Berkes and Ross 2013, Brown 2014). Further, some note a lack of normativity in the application of resilience thinking, along with a failure to address trade-offs and build equitable solutions (e.g., Bhadur and Tanner 2014). There is greater need to ask, and answer, the question "resilience for whom?" (Lebel et al. 2006, Leach 2008).

Within the broader call to understand social dynamics in SESs is the need to introduce a cultural perspective (Head 2009, Crane 2010, Davidson 2010, Brown and Westaway 2011). As Rotarangi and Russel (2010) argue, culturally sensitive methodologies for

${ }^{1}$ Policy, Economic and Social Sciences, WorldFish Center, ${ }^{2}$ Learning for Sustainability, ${ }^{3}$ Faculty of Environment, Society and Design, Lincoln University, ${ }^{4}$ Te Matapuna, Kaupapa Maori Unit, Faculty of Agriculture and Life Sciences, Lincoln University 
exploring resilience concepts are particularly important when working with marginalized communities such as indigenous peoples. Equally, scientific practice can benefit from working with the transdisciplinary frameworks of indigenous peoples (Allen et al. 2009).

We presents insights gained from adopting a cultural perspective to understand resilience and the associated social dynamics of SESs. We use the Guna indigenous community-based approach to governance as a case study. Because such processes are the product of coevolutionary relationships and are guided by an indigenous worldview, they are holistic in nature and embody the need for collective endeavor and adaptation. Collaboration and adaptation are required for dealing collectively with uncertainty and complexity (Armitage et al. 2009), and are also fundamental to many indigenous processes (Berkes and Berkes 2008). We introduce the indigenous Guna ${ }^{[1]}$ people of Panama as an example of a people that live embedded within an interlinked SES. Findings from participatory action research (PAR) are presented to highlight the use of social and cultural process lenses to understand and support adaptation and transformation and, hence, resilience in SESs.

\section{CHANGE, ADAPTATION, AND TRANSFORMATION IN SOCIAL-ECOLOGICAL SYSTEMS}

SESs are complex adaptive systems (CASs) characterized in terms of connections and patterns of relationships, historical (path) dependency, emergent behavior, and limited predictability (Byrne 1998, Cilliers 1998, Anderson and McDaniel 2000, Levin 2003). Theories about CASs remind us that such systems are not deterministic, predictable, and mechanistic, but rather are evolving and self-organizing with feedbacks between multiple parts and scales. Accordingly, understanding and managing change from this dynamic view of SESs are essential aspects of understanding and therefore maintaining resilience (Folke et al. 2010).

The internal dynamics of change in SESs are often described in terms of adaptation and transformation. Adaptation is the "capacity of a SES to learn, combine experience and knowledge and adjust its responses to changing external drivers and internal processes" (Folke et al. 2010). Adaptive capacity enables a system to retain the same structure and functions in the face of change. Adaptation, therefore, is related to coping with variability (Berkes and Jolly 2002, Adger et al. 2005) to maintain a certain internal state and relies on collective processes for facilitating learning and change. Transformational change, by contrast, is the ability to change to new arrangements when the current state is no longer viable. Transformation is understood as a change such that "what emerges is fundamentally different from what went before" (Gass 2010; Brookfield 2012:131). Adaptation and transformation are intimately linked within SESs; adaptation at one level may lead to a transformation at another level. The multiscalar nature of these changes makes it hard to distinguish clearly between adaptation and transformation (Pelling 2011).

Developing a direction and culture for change that underpin both adaptation and transformation for improved environmental management is not easy. Such change may upset beliefs and habits, and is therefore difficult to facilitate (Michael 1995). Argyris et al. (1985) point out that individuals and organizations can resist change, or learning, by preventing open dialogue and the integration of new information that may challenge their existing worldviews, including their values, assumptions, and paradigms. For transformative change in particular, people must become cognizant of their own and others' mental models to reflect critically upon them (Pelling 2011). Attaining the levels of critical reflection required for deep change to reorganize an SES is particularly difficult for contemporary societies. The challenges faced in supporting both adaptive and transformative change in SESs are not only technical, but also organizational, social, and psychological (Walters 1997, Gregory et al. 2006, Allen and Jacobson 2009, Huitema et al. 2009).

In response to these challenges, the social and human agency aspects within social-ecological governance models are receiving more attention. For example, adaptive governance (Dietz et al. 2003, Olsson et al. 2004, Folke et al. 2005) focuses on the processes that support social learning and identify collective action, leadership, networks, and institutional arrangements as important features. They distinguish transformational change by emphasizing that surprise and crises, often externally driven, are important conditions for bringing about deeper structural change, whereas the ability to use social memory and other aspects of social capital enable the internal response. Understanding such human dimensions of change can be enhanced through multidisciplinary insights (Leach 2008, Brown and Westaway 2011). Further, the way responses are envisioned and enacted within the system must reflect and engage with the values, contexts, and cultures of each community, thus enabling a normative interpretation of change. This calls for more situated studies of the key features that underpin SES adaptive behaviors.

The use of indigenous knowledge systems in environmental management underscores the way that the social and ecological are linked in physical, temporal, and spiritual ways. These links raise important considerations for those concerned with the social and human agency aspects of managing adaptation and transformation. These are particularly relevant if indigenous knowledge about the environment is viewed as a system through which indigenous peoples understand and engage in the world (Raffles 2002). Indigenous knowledge systems often characterize people, animals, plants, and other elements of the universe as an interconnected and interdependent network from which social relations and obligations arise (Roberts et al. 1995, International Council for Science 2002, Boilat et al. 2013, Holmes and Jampijinpa 2013). Moreover, as Allen et al. (2009) point out, goals that focus and drive indigenous engagement with the environment are typically long-term and are often intergenerational. These underlying worldviews create a particular context within which our understanding of how to manage SESs is embedded.

In spite of the opportunity that work with indigenous peoples presents for understanding adaptation and transformation, a recent Special Feature in this journal on integrating indigenous ecological knowledge with science (see Bohensky et al. 2013) illustrates that little emphasis is placed on exploring this knowledge within its cultural and spiritual context. We argue that the historical experiences of indigenous peoples that have coevolved with ecosystems provide opportunities to explore how relationships between societies and nature may be managed 
toward social-ecological resilience and sustainability, and can usefully inform change, both adaptation and transformation, across scales from the local to the global.

\section{RESEARCH CONTEXT}

The Comarca Guna Yala was the focus of this PAR endeavor. Guna Yala was the first semiautonomous indigenous territory of the Guna people to be established in Panama in 1954 and is made up of the San Blas Archipelago, which contains more than 400 coral islands and a forested strip of land from the Caribbean coast to the continental divide (Archibold and Daley 1993). This biocultural territory (Apgar et al. 2011) supports high levels of biodiversity in both its terrestrial and marine ecosystems. It maintains largely intact rainforest (Ventocilla et al. 1995) and more than $80 \%$ of the coral diversity of the entire Caribbean region of Panama (Guzmán 2003). The Guna peoples today still depend largely on agriculture, fishing, hunting, and gathering for their livelihoods. Increasingly, this once-isolated region of Panama is more connected to the world through improved transportation into the territory and upgraded telecommunications systems. As a result, subsistence activities are now supplemented with revenue-generating activities such as the sale of some marine species (Castillo and Lessios 2001), small ecotourism businesses (Snow and Wheeler 2000), and sale of crafts (Tice 1995). Increasingly, many Guna are traveling and living outside their territory to gain access to better formal education and jobs.

Despite these shifts in livelihood activities and the modernizing narrative, the Guna continue to demonstrate high levels of social cohesion and village life, which is still largely managed through their traditional governance mechanisms (Chapin 1991, Howe 2001, IWGIA 2006). These characteristics make the Guna indigenous approach a good case study for our purposes. The $B a b$ Igar is the Guna cultural and spiritual framework that guides engagement and participation of people in the world, and informs Guna governance practice. Bab Igala or Way of the Great Father ( $B a b$ refers to the Great Father, the cocreator of the world, and Igala or Igar means a path or a way) is also known as Anmar danikid igar (the story of where we come from; Wagua 2000). It is a compilation of stories that together make up a dynamic system of interpreting the world based on oral processes. Within them is the creation story of the Guna, which is similar to that of other indigenous peoples, in which the Great Father, the sky, and the Great Mother, the earth, procreated to produce life (Rose 2005). This view of the Guna as descendants and protectors of Mother Earth emphasizes identity and purpose.

The Bab Igar is promoted and continues to evolve through a combination of recounting stories through chanting by chiefs and interpretation and analysis by interpreters during communal gatherings (Howe 2002). In such an interconnected view of the world, all things and beings are part of one system, and all material things have burba, i.e., life or spirit. Plants, animals, rocks, minerals, and people all have burba. This whole-system view emphasizes a fundamental connectedness and relationship, and promotes continued reflection on identity and purpose in the world. The Guna spiritual framing explicitly connects people to the earth and guides all collective decision-making processes within their communal gatherings.

Today, Guna Yala is governed through two overarching institutions that were created by the Guna through historical negotiation and resistance to the colonizing forces (Howe 1998,
Wagua 2007). The Congreso General Guna is their political and administrative institution, whereas the Congreso General de la Cultura is the highest cultural and spiritual authority of Guna Yala. Each of the 49 communities that form part of the territory participates directly in the assemblies of their general congresses, which mirror the governance processes used in communities. These collective governance processes at both the community and Comarca levels are the vehicles for enacting and guiding the relationship between the social and environmental spheres of their territory.

The Guna provide an informative case through which to understand how indigenous social and cultural practice supports adaptive and transformative change. This is particularly because of their unusual situation of ongoing indigenous occupation of ancestral land and the relative success they have shown in continued adaptation through their collective governance. Further, the semiautonomous indigenous territory of Guna Yala can be analyzed as a bounded system through which interactions between the sociocultural and biophysical realms can be seen as organic and self-organizing processes within an SES.

\section{RESEARCH DESIGN AND METHODS}

The main objective that guided this PAR study was to build understanding of the underlying social and cultural processes that foster Guna adaptive capacity and their relationship to endogenous development of the biocultural territory of Guna Yala (Apgar 2010). Cote and Nightingale (2012:484) argue that understanding dimensions of power and agency in socialecological resilience requires understanding "situated systems and the cultural and political categories of specific context." The study of Guna cultural and social practices and processes did this through a PAR approach, which enables a collaborative process of inquiry seeking to answer questions and address real-life concerns in context (Reason and Bradbury 2008, Allen et al. 2014).

The inquiry process used both primary and secondary sources of information. Care was taken to triangulate across these different inquiry methods to ensure rigor (Apgar 2010). A specifically formed reflection group made up of Guna leaders and scholars engaged in iterative discussion cycles to collectively build conceptual clarity around the complex field of adaptive capacity in the Guna context. The real-life concern of participants that stimulated their reflections was their support of endogenous development as Guna scholars and leaders. As well as the main facilitated reflection process, a range of ongoing development projects provided additional opportunities for other groups to reflect on and make sense of adaptive capacity. These included a bilingual education project led by the Guna General Congress, a nongovernmental organization (NGO) managed marine resource management project, and an initiative to build a Guna leadership school. Ethnographic methods were used both within villages and within the Comarca governance processes for in-depth inquiry into particular areas of interest that emerged from the reflection process. This material was also triangulated with literature reviews. Grounded theory (Charmaz 2006) guided the development of theory in a collaborative manner with the reflection group and led to the final contributions to understanding the role of social and cultural practice in supporting Guna adaptive capacity. 


\section{RESEARCH PROCESS AND RESULTS}

There were three cycles of action and reflection within the PAR process through which conceptual clarity was sought, guidance on where to focus in-depth inquiry arose, and theory was developed. Figure 1 provides a summarized view of how three cycles of reflection formed the PAR process. The first led to understanding of enabling conditions for adaptation; the second pointed to the skills, knowledge, and practices that create the enabling conditions; and the third created a deeper understanding of the difference between adaptive and transformative capacity of the Guna.

Fig. 1. Three cycles of reflection that guided the participatory action research process.

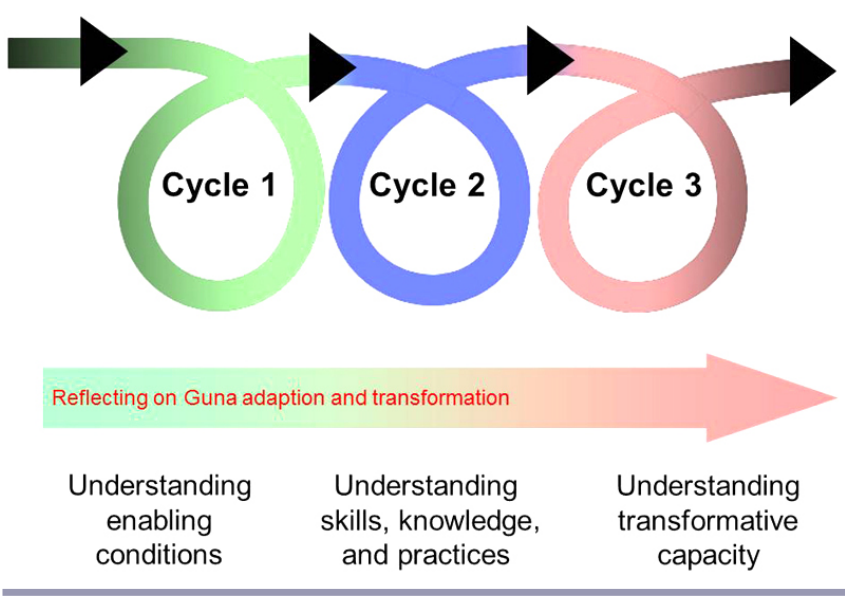

\section{Practices that enable Guna adaptation}

The CAS framing that informed the research process provided a starting point for the reflection group to explore and agree on key determinants of Guna adaptive capacity. Five core elements of Guna social and cultural practice emerged from the first reflection cycle as important for underlying adaptive capacity (Table 1). This work formed the basis for a second reflection cycle that identified the skills, knowledge, practices, and underlying processes that were found to be responsible for enabling adaptation in practice (see Table 1).

Thematic analysis across the identified knowledge, skills, and practices led to identification of three main themes of Guna social and cultural practices: leadership development, personhood development, and social networking. Each of these key areas was examined further through ethnographic methods. The major findings on their relationship to Guna adaptive capacity were discussed and checked with the main reflection group. The reflection group agreed that collectively these three areas can be seen to be crucial for supporting linked social aspects of adaptation that are recognized as being innovative and equitable. For each area, we engage with relevant literature to illustrate its contribution to understanding adaptation in SESs.

\section{Leadership, facilitating dialogue and reflection}

Much is already known about Guna leadership (Howe 1974, 1986, Chapin 1983) and its role in governance. The CAS framing of the inquiry provided a view of leadership as "a complex interactive dynamic through which adaptive outcomes emerge" (Uhl-Brien et al. 2007:314). This view was used to analyze the skills and characteristics of Guna leaders that support adaptation by facilitating the interaction of multiple agents to foster dialogue, reflection, and learning. This approach is similar to that described by Westley et al. (2013) of transformational leadership catalyzing change in complex SESs.

Table 1. Skills, knowledge, practices, and underlying processes that build enabling conditions for Guna adaptive capacity.

\begin{tabular}{ll}
\hline \hline $\begin{array}{l}\text { Enabling Conditions for } \\
\text { Adaptive Capacity }\end{array}$ & $\begin{array}{l}\text { Skills, knowledge, practices, and } \\
\text { underlying processes }\end{array}$ \\
\hline Use of collective memory & $\begin{array}{l}\text { Remember oral history } \\
\text { Observe natural cycles }\end{array}$ \\
Maintain a relationship with & $\begin{array}{l}\text { Context for relationship with nature } \\
\text { through Bab Igar }\end{array}$ \\
ecosystems & $\begin{array}{l}\text { Interact directly with nature } \\
\text { Individuals have collective identity }\end{array}$ \\
High social cohesion & $\begin{array}{l}\text { Diversity of groups within collective } \\
\text { Strong and tight social networks }\end{array}$ \\
Territorial autonomy \\
resources & $\begin{array}{l}\text { Institutional structures } \\
\text { Collective decision-making processes } \\
\text { Collective decision-making processes }\end{array}$ \\
Management of & Filter for incoming information \\
relationships with other & Structural links to other processes \\
knowledge systems & Input from diverse views
\end{tabular}

The reflection group found that Guna leaders traditionally foster community adaption primarily through facilitation and guidance during the communal gatherings that are central to collective governance in communities and at the Comarca level. Today, governance is manifest through a mixture of traditional structures and their associated roles, i.e., ritual specialists and spiritual leaders, and contemporary administrative and political processes and their associated roles, i.e., administrative and political leaders. The communal gatherings take a dialogical format, using principles such as respect, from the Bab Igar. Another Bab Igar principle is the ability to use the heart in decision making, which refers to the ability to allow emotion, identity, and intuition to help guide decisions. The way the Guna come together in dialogue is still largely defined by their spiritual and cultural framing, with leaders as the facilitators.

Leadership skills of traditional leaders are built through a long process of apprenticeship during which they learn specialized skills; for example, learning to become a curing therapeutic specialist involves acquiring knowledge of medicinal plants and therapeutic chants. The apprenticeship also provides opportunity for development of emotional and social intelligence, and as a result, produces knowledgeable and wise leaders, capacities known to be associated with transformational capacity in leaders (Bass 1990, Goleman 2006). Guna leaders are skilled in reflection, a practice that is built through the apprenticeship model of development and is essential for learning and change (Daudeline 1996). Guna leaders also travel and study under various specialist leaders across their territory and beyond. Their travels and exposure to other communities build an openness that is associated with innovation and creativity (Jansen et al. 2009). 
Relational personhood, supporting capacity for participation and engagement

The reflection group identified the capacity of the wider community for constructive engagement as critical to a collective approach to adaptive decision making. Importantly, two main behaviors of individuals support collective action and adaptive capacity: contributing as a member of the collective to show solidarity and behaving as a unique individual to leverage differences in the collective through the dialogical processes. These seemingly contradictory behaviors of Guna individuals were analyzed through Melucci's (1989) model of collective action and Harre's (1998) model of multiple selves. Combined, these models produce a holistic view of the personhood of individuals as being made up of multiple selves that enable multiple ways of engaging for collective action. This notion of personhood moves beyond the idea of people solely as agents in management of resources to people who are fully engaged in the SES and framed understanding of Guna behaviors that support adaptive capacity.

Guna governance depends heavily on the active participation of many community members, and collective identity is a motivating source for participation. Through our analysis of Guna personhood, the reflection group found that it is the result of practice in a web of interactions in very socially and physically tight communities (also described by Chapin 1991, Howe 2001). Development of personhood mimics the more formal process of leadership development and is based on experiential learning and guidance by a diversity of adults who together share the responsibility of raising children. The diversity of role models around children builds a view of community life and engagement with the collective as a diverse endeavor, with multiple and different ways of contributing to the whole.

Guna personhood is reinforced through the Bab Igar, which provides a theoretical framework for reciprocity and respect for all. What is interesting about the Guna case, however, is that their relational spirituality promotes individuality in persons. People learn to engage in the collective from their own knowledge base, e.g., expertise in fishing, and are encouraged to share their uniqueness in making collective decisions. As Edge (1998) argues to be true for Australian Aboriginal society, a holistic view of the world promotes relational people that interact as unique members of the group. The agency of Guna individuals, which is a key driver of adaptive capacity, is developed through their experiential development as whole persons, and the Guna worldview plays an important role. This is significant for adaptive capacity, because it provides diversity that is key to transdisciplinary decision making (Apgar et al. 2009) and managing complexity.

Resilient social networks, supported through informal interactions The third group of practices we found to be important for adaptive capacity relate to how the Guna build a web of interactions through which adaptive capacity is fostered. Social networks analyzed as part of social capital (Putnam 2000) have helped us understand the value of bridging links, those that link across different groups, communities, and scales. For adaptive governance, bridging and cross-scale linkages have been shown to be important (Singleton 1998, Olsson et al. 2004, Carlsson and Berkes 2005, Hahn et al. 2006).

We analyzed the dynamic process of social networking through understanding it in situ, looking both at the structures and functions of social networks in Guna Yala. In communities we found that interactions continuously create new interest groups that form around entrepreneurial or other activities. The groups are connected through leaders who come together in the collective decision-making forums to share information from diverse community activities and interest groups, e.g., from youth cultural groups to a women's savings group. It is not the formal structures of governance that enable information to be shared across groups, but rather the organic and informal interactions in community life that create a web of interactions through which adaptation emerges. The dynamic nature of the changing roles of group leaders means that the network does not become vulnerable because of dependence on only a few hubs to maintain bridging links.

To understand the relationships created between those involved in governance processes, we also looked at the network structures and social functions across scales, from the community to the Comarca level. We found that cross-scale links are encouraged through identification of specific roles for bridging. The sikwis are people who do not necessarily hold a formal leadership role, but who are considered important for information sharing because of their roles in other spaces and are called on during collective forums. These links extend beyond the Comarca. For example, NGO leaders are recognized as important for sharing information from the external spaces that is relevant for Guna governance. We also found that it is mainly through informal relationships between those engaged in governance processes that information sharing is ensured. In this way Guna governance structures and processes enable the web of interactions through which adaptation emerges.

In the language of networks, Guna social networks in communities and in their Comarca governance processes mimic the "small world" network typology (e.g., Watts and Stogatz 1998, Cumming 2011) that brings a number of benefits that support resilience. Although this analysis of Guna networking did not reveal any surprises, it helped us understand the role that cultural practice plays in supporting interactions that are akin to the shadow networks that Pelling et al. (2008) describe as important to overcome social barriers to adaptation.

\section{Guna cultural practice fostering transformative capacities}

The final reflection cycle with the reflection group reminded us to look across the three areas of Guna practice found to be important for adaptive capacity. The CAS framing of the design and analysis instructed us that it is not one variable that leads to adaptive capacity or system resilience, but rather, it is how the variables mesh together to enable a system property to emerge. The reflection group agreed that a more holistic view of adaptation would be enabled by building on the in-depth analysis of the key practices and seeing how they link through looking across them at the governance processes through which change is fostered. We could discern two different levels of change, akin to adaptation and transformation. Upon deeper reflection on the two levels of change, we found that as well as the practices that enable adaptation, i.e., leadership, personhood development, and networking, certain cultural practices of the Guna demonstrate how additional skills are developed to open up the potential for transformative change.

The Bab Igar framework of the Guna that guides individual and collective decision making makes explicit the unity in the system, while recognizing that different views and mental models are part 
of it. Individuals can see themselves as parts of the whole, which affirms their views and, in so doing, creates a safe space for collective critical reflection and creativity. The safe space is most obviously achieved through ritual practice. The Guna engage in various forms of individual and collective rituals that are all celebrated in the Bab Igar and have caught the attention of many ethnographers over the years (e.g., Chapin 1983, Sherzer 1990, Howe 2009). Our interest in transformative change from an SES framing revealed particular capacities that are built through ritual practice.

The coming-of-age ritual of young women, for example, is composed of several events that can take place over a number of years, some of which are the most awaited social events. Young girls who experience this rite of passage engage in periods of isolation and instruction that together provide opportunity for critical self-reflection in an emotional setting. Van Gennep's (1960) concept of "liminality" describes the transition that individuals go through as they journey to a new identity and reality. Young girls experience such liminality and emerge as women. Through analysis of this process, we found that their experience indicates that capacity for critical self-reflection and creativity is built through engagement in rituals. Young girls reported that a heightened sense of identity develops through the process, which is critical to the adaptive process and personhood development described in the previous section. This particular ritual experience provides an excellent example of how a Guna ritual builds capacity for critical self-reflection and enables development of new paths forward for individuals. Many others provide similar opportunities, and a majority of Guna people living in the Comarca continue to engage in them. As a consequence, most Guna individuals have had some experience with critical self-reflection, a skill that is pivotal to deep engagement.

The war uet (known by other names as well) ritual of the Guna is the best example of how ritual enables collective reflection for transformative change. It is engaged in infrequently, only in times of crisis and social imbalance caused, e.g., by sudden deaths or a malaria epidemic. During a war uet ritual, the community is involved in a collective gathering that lasts eight days, guided by a ritual specialist who uses chanting to enter the spirit world to engage with the underlying cause of the disruption. Although the Guna smoke tobacco collectively during the ritual, its use does not have evident physiological effects such as those from use of hallucinogens by Amazonian tribes, which have also been reported to support transformation (Lewis 2008). For the Guna, the collective experience of the ritual contributes to public liminality or, as Turner (1974) calls it, "communitas," a collective experience during which people feel connected. Communitas is visible in rituals such as those that occur during rites of passage and times of crisis. These are liminal, or transition, times when society is at a crossroads. By helping people to step out of their normal social structure, these rituals provide people with an opportunity to reflect on that structure and to develop new and innovative pathways forward.

The two examples of Guna rituals described illustrate how cultural and spiritual practices are effective tools for providing individual and collective safe spaces for critical reflection, deep engagement, and innovation. These individual and collective capacities offer a vehicle for overcoming the key challenges faced in bringing forth transformative change.

\section{DISCUSSION}

The Guna case study has shown how exploring adaptation and transformation through in situ cases that recognize cultural and spiritual practices can deepen our understanding of the practices that the adaptive governance (Dietz et al. 2003, Folke et al. 2005) model has identified. It seems that the creativity and innovation required in responding to opportunities for change are driven through these cultural and spiritual practices. At the heart of managing complexity lies the ability to manage innovation and conservation within a CAS (Anderson and McDaniel 2000, Rammel 2005). The Guna use the Bab Igar, which provides a longterm coevolutionary view together with dialogical and transdisciplinary practices that enable new solutions. The cultural realm of life and enacted agency through the Bab Igar is important for managing such paradoxical systems.

The three areas of practice that emerged as important for Guna adaptive and transformative capacity connect with and extend those recently reported by others (e.g., Ross et al. 2010, Berkes and Ross 2013, Maclean et al. 2014). Leadership is discussed in the resilience literature (e.g., Westley et al. 2013), and our findings build on this to illustrate the central role that cultural practices of leadership development play in enabling leadership in SESs. Understanding social networks, particularly the role of shadow networks in adaptive governance, is discussed in the literature (e.g., Olsson et al. 2006), but the Guna case study adds depth to our understanding of how they are developed through cultural practice.

Personhood, however, is less discussed in the literature. The cultural practice lens used in the case study has revealed that human agency, a core motivator for social change and therefore adaptation and transformation in SESs, is nurtured through nested levels of collective engagement from the family to the community and requires use of rituals. Further understanding of agency at the individual level and the seemingly contradictory behavior of engaging from one's own perspective mediated through collective identity and the role this plays in supporting adaptation are areas worthy of more attention in the study of SES dynamics.

As Crane (2010) has highlighted, recognition of the material, social, and symbolic landscape contextualizes the experience of change, and in the case of the Guna, it is the Bab Igar that guides their change process through providing both a framework and guidance for behaviors and practice. Like other indigenous frameworks, it couches well-being in a cultural and spiritual understanding. Further, it guides decision making through ensuring that people link the context of the present with past experiences and categories of interpretation, the impact of the current experience, and its likely effect on future generations. This builds a richer picture around the argument of Folke et al. (2005) that using social memory is critical for adaptive governance. It also highlights Olsson et al.'s (2004) identification of the need for a comprehensive framework to guide adaptive governance. The Guna enact the human dimensions of resilience that relate to imagination, anticipation, and motivation of collective action (Davidson 2010) through their spiritual framing and collective practices, building relational personhood, dialogical leaders, and resilient social networks. Our inquiry into the situated experience of adaptive capacity of the Guna people adds to current understanding of adaptive and transformative capacities an 
appreciation of cultural and ritual practice as underlying processes that both build and leverage latent adaptive capacities (Pelling and High 2005).

Beyond being able to learn and change, the Guna are also able to critique and reimagine the current system when a felt disconnect between values and day-to-day life occurs. The war uet rituals enable this questioning through a guided process that emphasizes identity and belonging, thus creating a safe space to enter what are normally challenging collective spaces. At times of crises, the Guna are able to respond not just through using information that is available at hand, but also by using their individual and collective capacity to reflect in a deeper sense. What the Guna show us is that the agency that leads to transformative change is developed through spiritual and ritual practices that individuals engage in throughout their lives. As a result, these individuals collectively become open to and therefore activate their latent adaptive capacities. Without an appreciation of Guna cultural and spiritual practice, it would be difficult to understand how they foster transformative change or how it is distinct from adaptation.

\section{CONCLUSION}

We have claimed that longstanding indigenous practices provide ideal case studies for investigating processes of resilience and sustainability that combine social and ecological systems. We have also argued that building understanding of human agency is best done through in-depth analysis and engagement that enable a view of social and cultural practice in situ. We focused the collaborative study on understanding processes of social change that support adaptation and transformation. Our starting point was to recognize that these levels of change are intricately linked within SESs and are differentiated by the depth of change they represent.

Through building a holistic understanding of the Guna governance system and engaging with Guna leaders to ensure their voice in the process and analysis, we have shown that adaptation and transformation are nested. At one level, open, networked processes of governance and management allow for the emergence of collective responses and decision making concerning particular challenges. At a second, deeper level, cultural and spiritual processes are woven into the governance process when faced with critical challenges to the SES. These processes and practices tap the creative and innovative potential of the culture and people through the creation of safe spaces for the expression, emergence, and enactment of adaptive and transformative possibilities. ${ }^{[1]}$ Recently the Guna have developed a standardized orthography for their language in which the letter "g" replaces previous use of the letter " $k$." In this paper we use the new orthography while recognizing that many references and earlier writing on this topic still use the word Kuna.

Responses to this article can be read online at: http://www.ecologyandsociety.org/issues/responses. $\mathrm{php} / 7314$

\section{Acknowledgments:}

We thank the Congreso General Guna and the Congreso General de la Cultural Guna for permission granted to Marina Apgar to conduct collaborative research in Guna Yala. We respectfully acknowledge the wisdom and intellectual contributions of the group NEGA and Guna leaders who were coresearchers in the participatory action research. We thank Lincoln University for supporting this research.

\section{LITERATURE CITED}

Adger, W. N. 2010. Addressing barriers and social challenges of climate change adaptation. Pages 79-84 in P. C. Stern and R. E. Kasperson, editors. Facilitating climate change responses: report on knowledge from the social and behavioural sciences. National Academies of Science, Washington D.C., USA.

Adger, W. N., T. P. Hughes, C. Folke, S. R. Carpenter, and J. Rockström. 2005. Social-ecological resilience to coastal disasters. Science 309(5737):1036-1039. http://dx.doi.org/10.1126/science.1112122

Allen, W., J. M. Ataria, J. M. Apgar, G. Harmsworth, and L. A. Tremblay. 2009. Kia pono te mahi putaiao - doing science in the right spirit. Journal of the Royal Society of New Zealand 39 (4):239-242. http://dx.doi.org/10.1080/03014220909510588

Allen, W., and C. Jacobson. 2009. Learning about the social elements of adaptive management in the South Island tussock grasslands of New Zealand. Pages 95-114 in C. Allan and G. H. Stansky, editors. Adaptive environmental management: a practitioner's guide. Springer, Berlin, Germany. http://dx.doi. org/10.1007/978-1-4020-9632-7 6

Allen, W., S. Ogilvie, H. Blackie, D. Smith, S. Sam, J. Doherty, D. McKenzie, J. Ataria, L. Shapiro, J. McKay, E. Murphy, C. Jacobson, and C. Eason. 2014. Bridging disciplines, knowledge systems and cultures in pest management. Environmental Management 53(2):429-440. http://dx.doi.org/10.1007/s00267-013-0180$\underline{\mathrm{Z}}$

Anderson, R. A., and R. R. McDaniel, Jr. 2000. Managing health care organizations: where professionalism meets complexity science. Health Care Management Review 25(1):83-92. http://dx. doi.org/10.1097/00004010-200001000-00010

Apgar, J. M. 2010. Adaptive capacity for endogenous development of Kuna Yala, an indigenous biocultural system. Dissertation. Lincoln University, Lincoln, New Zealand. [online] URL: http:// hdl.handle.net/10182/3457

Apgar, J. M., A. Argumedo, and W. J. Allen. 2009. Building transdisciplinarity for managing complexity: lessons from indigenous practice. International Journal of Interdisciplinary Social Sciences 4(5):255-270.

Apgar, J. M., J. M. Ataria, and W. J. Allen. 2011. Managing beyond designations: supporting endogenous processes for nurturing biocultural development. International Journal of Heritage Studies 17(6):555-570. http://dx.doi.org/10.1080/13527258.2011.618250

Archibold, G., and S. Daley. 1993. Kuna Yala: protecting the San Blas of Panama. Pages 52-57 in E. Kemf, editor. The law of the mother, protecting indigenous peoples in protected areas. Sierra Club, San Francisco, California, USA.

Argyris, C., R. Putnam, and D. M. Smith. 1985. Action science: concepts, methods, and skills for research and intervention. JosseyBass, San Francisco, California, USA. ISBN 0-87589-665-0. 
Armitage, D., C. Béné, A. T. Charles, D. Johnson, and E. H. Allison. 2012. The interplay of well-being and resilience in applying a social-ecological perspective. Ecology and Society 17 (4): 15. http://dx.doi.org/10.5751/ES-04940-170415

Armitage, D. R., R. Plummer, F. Berkes, R. I. Arthur, A. T. Charles, I. J. Davidson-Hunt, A. P. Diduck, N. C. Doubleday, D. S. Johnson, M. Marschke, P. McConney, E. W. Pinkerton, and E. K. Wollenberg. 2009. Adaptive co-management for socialecological complexity. Frontiers in Ecology and the Environment 7(2):95-102. http://dx.doi.org/10.1890/070089

Bahadur, A., and T. Tanner. 2014. Transformational resilience thinking: putting people, power and politics at the heart of urban climate resilience. Environment \& Urbanization 26(1):200-214. http://dx.doi.org/10.1177/0956247814522154

Bass, B. M. 1990. From transactional to transformational leadership: learning to share the vision. Organizational Dynamics 18(3):19-31. http://dx.doi.org/10.1016/0090-2616(90)90061-S

Berkes, F., and M. K. Berkes. 2008. Ecological complexity, fuzzy logic, and holism in indigenous knowledge. Futures 41(1):6-12. http://dx.doi.org/10.1016/j.futures.2008.07.003

Berkes, F., J. Colding, and C. Folke. 2000. Rediscovery of traditional ecological knowledge as adaptive management. Ecological Applications 10(5):1251-1262. http://dx.doi. org/10.1890/1051-0761(2000)010[1251:ROTEKA]2.0.CO;2

Berkes, F., J. Colding, and C. Folke. 2003. Navigating socialecological systems: building resilience for complexity and change. Cambridge University Press, Cambridge, UK.

Berkes, F., and C. Folke. 1998. Linking social and ecological systems for resilience and sustainability. Pages 13-20 in F. Berkes and C. Folke, editors. Linking social and ecological systems: management practices and social mechanisms for building resilience. Cambridge University Press, New York, New York, USA.

Berkes, F., and D. Jolly. 2002. Adapting to climate change: socialecological resilience in a Canadian western Arctic community. Conservation Ecology 5(2):18. [online] URL: http://www. consecol.org/vol5/iss2/art18/

Berkes, F., and H. Ross. 2013. Community resilience: toward an integrated approach. Society \& Natural Resources 26(1):5-20. http://dx.doi.org/10.1080/08941920.2012.736605

Bohensky, E. L., J. R. A. Butler, and J. Davies. 2013. Integrating indigenous ecological knowledge and science in natural resource management: perspectives from Australia. Ecology and Society 18(3): 20. http://dx.doi.org/10.5751/ES-05846-180320

Boillat, S., E. Serrano, S. Rist, and F. Berkes. 2013. The importance of place names in the search for ecosystem-like concepts in indigenous societies: an example from the Bolivian Andes. Environmental Management 51:663-678. http://dx.doi. org/10.1007/s00267-012-9969-4

Brookfield, S. D. 2012. Critical theory and transformative learning. Pages 131-146 in E. W. Taylor and P. Cranton, editors. The handbook of transformative learning: theory, research and practice. Jossey-Bass, San Francisco, California, USA.
Brown, K. 2014. Global environmental change I: a social turn for resilience? Progress in Human Geography 38(1):107-117. http://dx. doi.org/10.1177/0309132513498837

Brown, K., and E. Westaway. 2011. Agency, capacity, and resilience to environmental change: lessons from human development, well-being, and disasters. Annual Review of Environment and Resources 36(1):321-342. http://dx.doi. org/10.1146/annurev-environ-052610-092905

Buikstra, E., H. Ross, C. A. King, P. G. Baker, D. Hegney, K. McLachlan, and C. Rogers-Clark. 2010. The components of resilience-perceptions of an Australian rural community. Journal of Community Psychology 38(8):975-991. http://dx.doi. org/10.1002/jcop.20409

Byrne, D. S. 1998. Complexity theory and the social sciences: an introduction. Routledge, London, UK. ISBN 0-41516-296-3.

Carlsson, L., and F. Berkes. 2005. Co-management: concepts and methodological implications. Journal of Environmental Management 75(1):65-76. http://dx.doi.org/10.1016/j.jenvman.2004.11.008

Castillo, A., and H. A. Lessios. 2001. Lobster fishery by the Kuna indians in the San Blas region of Panama (Kuna Yala). Crustaceana 74(5):459-475. http://dx.doi.org/10.1163/15685400$\underline{1750243045}$

Chapin, N. M. 1983. Curing among the San Blas Kuna of Panama. University Microfilms International, Ann Arbor, Michigan, USA.

Chapin, N. M. 1991. Losing the way of the Great Father: the Kuna indians of Panama. New Scientist 1781(46):40-44.

Charmaz, K. 2006. Constructing grounded theory. Sage, Thousand Oaks, California, USA. ISBN 978-08-570-2914-0.

Cilliers, P. 1998. Complexity and postmodernism. Routledge, London, UK.

Cote, M., and A. J. Nightingale. 2012. Resilience thinking meets social theory: situating social change in social-ecological systems (SES) research. Progress in Human Geography 36(4):475-489. http://dx.doi.org/10.1177/0309132511425708

Crane, T. A. 2010. Of models and meanings: cultural resilience in socio-ecological systems. Ecology and Society 15(4): 19. [online] URL: http://www.ecologyandsociety.org/vol15/iss4/art19/

Cumming, G. S. 2011. Spatial resilience in social-ecological systems. Springer, Dordrecht, The Netherlands. ISBN 978-94-007-0307-0. http://dx.doi.org/10.1007/978-94-007-0307-0

Daudeline, M. W. 1996. Learning from experience through reflection. Organizational Dynamics 24(3):36-48. http://dx.doi. org/10.1016/B978-0-7506-7223-8.50016-2

Davidson, D. J. 2010. The applicability of the concept of resilience to social systems: some sources of optimism and nagging doubts. Society \& Natural Resources 23(12):1135-1149. http://dx.doi. org/10.1080/08941921003652940

Dietz, T., E. Ostrom, and P. Stern. 2003. The struggle to govern the commons. Science 302(5652):1907-1912. http://dx.doi. org/10.1126/science.1091015 
Edge, H. L. 1998. Individuality in a relational culture: a comparative study. Pages 31-40 in $\mathrm{H}$. Wautischer, editor. Tribal epistemologies: essays in the philosophy of anthropology. Avebury, London, UK.

Folke, C., S. Carpenter, T. Elmqvist, L. Gunderson, C. S. Holling, and B. Walker. 2002. Resilience and sustainable development: building adaptive capacity in a world of transformations. Ambio 31(5):437-440. http://dx.doi.org/10.1579/0044-7447-31.5.437

Folke, C., S. R. Carpenter, B. Walker, M. Scheffer, T. Chapin, and J. Rockström. 2010. Resilience thinking: integrating resilience, adaptability and transformability. Ecology and Society 15(4): 20. [online] URL: http://www.ecologyandsociety.org/vol15/iss4/ $\underline{\operatorname{art} 20 /}$

Folke, C., T. Hahn, P. Olsson, and J. Norberg. 2005. Adaptive governance of social-ecological systems. Annual Review of Environment and Resources 30(1):441-473. http://dx.doi. org/10.1146/annurev.energy.30.050504.144511

Gass, R. 2010. What is transformational change? Pages 12-14 in R. Gass, editor. Framing deep change: essays on transformative social change. Center for Transformative Change, Berkeley, California, USA.

Goleman, D. 2006. Social intelligence: the new science of human relationships. Bantam, New York, New York, USA. ISBN 0-55338-449-X.

Gregory, R., L. Failing, and P. Higgins. 2006. Adaptive management and environmental decision making: a case study application to water use planning. Ecological Economics 58 (2):434-447. http://dx.doi.org/10.1016/j.ecolecon.2005.07.020

Gunderson, L. H., and C. S. Holling. 2002. Panarchy: understanding transformations in human and natural systems. Island Press, Washington, D.C., USA. ISBN 1-55963-857-5.

Guzmán, H. M. 2003. Caribbean coral reefs of Panama: present status and future perspectives. Pages 241-273 in J. Cortes, editor. Latin American coral reefs. Elsevier Science, Amsterdam, The Netherlands. http://dx.doi.org/10.1016/B978-044451388-5/50012-6

Hahn, T., P. Olsson, C. Folke, and K. Johansson. 2006. Trustbuilding, knowledge generation and organizational innovations: the role of a bridging organization for adaptive comanagement of a wetland landscape around Kristianstad, Sweden. Human Ecology 34(4):573-592 http://dx.doi.org/10.1007/s10745-006-9035$\underline{\mathrm{Z}}$

Harre, R. 1998. The singular self. Sage, Thousand Oaks, California, USA. ISBN 1-44623-876-8.

Head, L. 2009. Cultural ecology: adaptation-retrofitting a concept? Progress in Human Geography 34(2):234-242. http://dx. doi.org/10.1177/0309132509338978

Holmes, M. C. C., and W. (S. P.) Jampijinpa. 2013. Law for country: the structure of Warlpiri ecological knowledge and its application to natural resource management and ecosystem stewardship. Ecology and Society 18(3): 19 http://dx.doi. org/10.5751/ES-05537-180319

Howe, J. 1974. Village political organization among the San Blas Cuna. University Microfilms International, Ann Arbor, Michigan, USA.
Howe, J. 1986. The Kuna gathering: contemporary village politics in Panama. University of Texas Press, Austin, Texas, USA.

Howe, J. 1998. A people who would not kneel: Panama, the United States, and the San Blas Kuna. Smithsonian Institution Press, Washington, D.C., USA. ISBN 1-56098-865-7.

Howe, J. 2001. The Kuna of Panama. Pages 137-152 in S. C. Sonich, editor. Endangered peoples of Latin America: struggles to survive and thrive. Greenwood, Westport, Connecticut, USA.

Howe, J. 2002. The Kuna gathering: contemporary village politics in Panama. Fenestra, Tucson, Arizona, USA. ISBN 1-58736-111-6.

Howe, J. 2009. Chiefs, scribes and ethnographers: Kuna culture from inside and out. University of Texas Press, Austin, Texas, USA. ISBN 978-02-927-2110-4.

Huitema, D., E. Mostert, W. Egas, S. Moellenkamp, C. PahlWostl, and R. Yalcin. 2009. Adaptive water governance: assessing the institutional prescriptions of adaptive (co-)management from a governance perspective and defining a research agenda. Ecology and Society 14(1): 26. [online] URL: http://www.ecologyandsociety. org/vol14/iss1/art26/

International Council for Science. 2002. Science, traditional knowledge and sustainable development. ICSU Series on Science for Sustainable Development No. 4. International Council for Science, Paris, France. [online] URL: http://unesdoc.unesco.org/ images/0015/001505/150501eo.pdf

International Work Group for Indigenous Affairs (IWGIA). 2006. The indigenous world. IWGIA, Copenhagen, Denmark. [online] URL: http://www.iwgia.org/iwgia_files_publications_files/ IW 2006.pdf

Jansen, J. J. P., D. Vera, and M. Crossan. 2009. Strategic leadership for exploration and exploitation: the moderating role of environmental dynamism. Leadership Quarterly 20(1):5-18. http://dx.doi.org/10.1016/j.leaqua.2008.11.008

Kates, R. W., W. R. Travis, and T. J. Wilbanks. 2012. Transformational adaptation when incremental adaptations to climate change are insufficient. Proceedings of the National Academy of Sciences of the United States of America 109 (19):7156-7161. http://dx.doi.org/10.1073/pnas.1115521109

Kerr, R. A. 2007. The looming oil crisis could arrive uncomfortably soon. Science 316(5825):351. http://dx.doi. org/10.1126/science.316.5823.351

Leach, M., editor. 2008. Re-framing resilience: a symposium reporte. STEPS Centre, Brighton, UK. [online] URL: http://stepscentre.org/wp-content/uploads/Resilience.pdf

Lebel, L., J. M. Anderies, B. Campbell, C. Folke, S. HatfieldDodds, T. P. Hughes, and J. Wilson. 2006. Governance and the capacity to manage resilience in regional social-ecological systems. Ecology and Society 11(1): 19. [online] URL: http://www. ecologyandsociety.org/vol11/iss1/art19/

Levin, S. A. 2003. Complex adaptive systems: exploring the known, the unknown and the unknowable. Bulletin of the American Mathematical Society 40(1):3-19. http://dx.doi. org/10.1090/S0273-0979-02-00965-5 
Lewis, S. E. 2008. Ayahuasca and spiritual crisis: liminality as space for personal growth. Anthropology of Consciousness 19 (2):109-133. http://dx.doi.org/10.1111/j.1556-3537.2008.00006.x

Ludwig, D., B. Walker, and C. S. Holling. 1997. Sustainability, stability, and resilience. Conservation Ecology 1(1): 7. [online] URL: http://www.consecol.org/vol1/iss1/art7/

Maclean, K., M. Cuthill, and H. Ross. 2014. Six attributes of social resilience. Journal of Environmental Planning and Management 57(1):144-156. http://dx.doi.org/10.1080/09640568.2013 .763774

Marshall, N., P. Marshall, and A. Abdulla. 2009. Using social resilience and resource dependency to increase the effectiveness of marine conservation initiatives in Salum, Egypt. Journal of Environmental Planning and Management 52(7):901-918. http:// dx.doi.org/10.1080/09640560903180982

Melluci, A. 1989. Nomads of the present: social movements and individual needs in contemporary society. Hutchinson Radius, London, UK. ISBN 0-87722-599-0.

Michael, D. N. 1995. Barriers and bridges to learning in a turbulent human ecology. Pages 461-485 in L. H. Gunderson, C. S. Holling, and S. S. Light, editors. Barriers and bridges to the renewal of ecosystems and institutions. Columbia University Press, New York, New York, USA.

Mimura, N., R. S. Pulwarty, D. M. Duc, I. Elshinnawy, M. H. Redsteer, H.-Q. Huang, J. N. Nkem, and R. A. Sanchez Rodriguez. 2014. Adaptation planning and implementation. Pages 869-898 in C. B. Field, V. R. Barros, D. J. Dokken, K. J. Mach, M. D. Mastrandrea, T. E. Bilir, M. Chatterjee, K. L. Ebi, Y. O. Estrada, R. C. Genova, B. Girma, E. S. Kissel, A. N. Levy, S. MacCracken, P. R. Mastrandrea, and L. L. White, editors. Climate change 2014: impacts, adaptation, and vulnerability. Part A: Global and sectoral aspects. Working Group II contribution to the Fifth Assessment Report of the Intergovernmental Panel on Climate Change. Cambridge University Press, New York, New York, USA. [online] URL: http://www.ipcc.ch/report/ar5/wg2/

Olsson, P., C. Folke, and T. Hahn. 2004. Social-ecological transformation for ecosystem management: the development of adaptive co-management of a wetland landscape in southern Sweden. Ecology and Society 9(4): 2. [online] URL: http://www. ecologyandsociety.org/vol9/iss4/art2/

Olsson, P., L. H. Gunderson, S. R. Carpenter, P. Ryan, L. Lebel, C. Folke, and C. S. Holling. 2006. Shooting the rapids: navigating transitions to adaptive governance in social-ecological systems. Ecology and Society 11(1): 18. [online] URL: http://www. ecologyandsociety.org/vol11/iss1/art18/

Park, S. E., N. A. Marshall, E. Jakku, A. M. Dowd, S. M. Howden, E. Mendham, and A. Fleming. 2012. Informing adaptation responses to climate change through theories of transformation. Global Environmental Change 22(1):115-126. http://dx.doi. org/10.1016/j.gloenvcha.2011.10.003

Pelling, M. 2011. Adaptation to climate change: from resilience to transformation. Taylor \& Francis, London, UK. ISBN 0-41547-751-4.
Pelling, M., and C. High. 2005. Understanding adaptation: what can social capital offer assessments of adaptive capacity? Global Environmental Change 15:308-319. http://dx.doi.org/10.1016/j. gloenvcha.2005.02.001

Pelling, M., C. High, J. Dearing, and D. Smith. 2008. Shadow spaces for social learning: a relational understanding of adaptive capacity to climate change within organisations. Environment and Planning A 40(4):867-884. http://dx.doi.org/10.1068/a39148

Pelling, M., and D. Manuel-Navarrete. 2011. From resilience to transformation: the adaptive cycle in two Mexican urban centers. Ecology and Society 16(2): 11. [online] URL: http://www. ecologyandsociety.org/vol16/iss2/art11/

Preston, B. L., K. Dow, and F. Berkhout. 2013. The climate adaptation frontier. Sustainability 5(3):1011-1035. http://dx.doi. org/10.3390/su5031011

Putnam, R. 2000. Bowling alone: the collapse and revival of American community. Simon \& Schuster, New York, New York, USA. ISBN 0-74320-304-6. http://dx.doi.org/10.1145/358916.361990

Raffles, H. 2002. Intimate knowledge. International Social Science Journal 54(173):325-336. http://dx.doi.org/10.1111/1468-2451.00385

Rammel, C. 2005. The paradox of sutainable development. Pages 1-30 in A. D. Maples, editor. Sustainable development: new research. Nova, New York, New York, USA.

Reason, P., and H. Bradbury. 2008. Introduction. Pages 5-10 in P. Reason and H. Bradbury, editors. The Sage handbook of action research: participative inquiry and practice. Sage, Thousand Oaks, California, USA.

Richardson, K., W. Steffen, H. J. Schellnhuber, J. Alcamo, T. Barker, D. M. Kammen, R. Leemans, D. Liverman, M. Munasinghe, B. Osman-Elasha, N. Stern, and O. Wæver. 2009. Climate change: global risk, challenges \& decisions. Copenhagen, 10-12 March. Synthesis report. University of Copenhagen, Copenhagen, Demark. [online] URL: http://climatecongress.ku. dk/pdf/synthesisreport

Roberts, M., W. Norman, N. Minhinnick, D. Wihongi, and C. Kirkwood. 1995. Kaitiakitanga: Maori perspective on conservation. Pacific Conservation Biology 2:7-20

Rose, D. 2005. An indigenous philosophical ecology: situating the human. Australian Journal of Anthropology 16(3):294-305. http:// dx.doi.org/10.1111/j.1835-9310.2005.tb00312.x

Ross, H., M. Cuthill, K. Maclean, D. Jansen, and B. Witt. 2010. Understanding, enhancing and managing for social resilience at the regional scale: opportunities in North Queensland. Report to the Marine and Tropical Sciences Research Facility. Reef and Rainforest Research Centre, Cairns, Australia. [online] URL: http://rrrc.org.au/wp-content/uploads/2014/06/497-UQ-Ross-Het-al-2010-Social-Resilience-at-the-Regional-Scale.pdf

Rotarangi, S., and D. Russel. 2010. Social-ecological resilience thinking: can indigenous culture guide environmental management? Journal of the Royal Society of New Zealand 39 (4):209-213. 
Sherzer, J. 1990. Verbal art in San Blas: Kuna culture through its discourse. Cambridge University Press, Cambridge, UK. ISBN 0-52138-513-X.

Singleton, S. 1998. Constructing cooperation: the evolution of institutions of comanagement. University of Michigan Press, Ann Arbor, Michigan, USA. ISBN 0-47210-957-X.

Snow, S. G., and C. L. Wheeler. 2000. Pathways in the periphery: tourism to indigenous communities in Panama. Social Sciences Quarterly 81(3):732-749.

Tice, K. E. 1995. Kuna crafts, gender, and the global economy. University of Texas Press, Austin, Texas, USA. ISBN 0-29278-137-7.

Turner, B. L., II. 2010. Vulnerability and resilience: coalescing or paralleling approaches for sustainability science? Global Environmental Change 20(4):570-576. http://dx.doi.org/10.1016/ j.gloenvcha.2010.07.003

Turner, V. 1974. Dramas, fields and metaphors: symbolic action in human society. Cornell University Press, Ithaca, New York, USA. ISBN 0-80149-151-7.

Uhl-Bien, M., R. Marion, and B. McKelvey. 2007. Complexity leadership theory: shifting leadership form the industrial age to the knowledge era. Leadership Quarterly 18(4):298-318.

United Nations Environment Programme (UNEP). 2009. UNEP yearbook 2009: new science and development in our changing environment. UNEP, Nairobi, Kenya. [online] URL: http://www. unep.org/yearbook/2009/

Van Gennep, A. 1960. The rites of passage. Translated by M. B. Vizedom and G. L. Caffee. University of Chicago Press, Chicago, Illinois, USA.

Ventocilla, J., H. Herrera, and V. Nuñez. 1995. Plants and animals in the life of the Kuna. University of Texas Press, Austin, Texas, USA.

Wagua, A. 2000. En defensa de la vida y su armonia: elementos de la religion Kuna. Textos del Bab Igala. Instituto de Investigacion Koskun Kalu, Kuna Yala, Panama.

Wagua, A. 2007. Así lo vi así me lo contaron. Second edition. Nan Garburba Oduloged Igar, Proyecto de Educación Bilingüe Intercultural en Territorios Kunas de Panama, Panama City, Panama.

Walker, B., C. S. Holling, S. R. Carpenter, and A. Kinzig. 2004. Resilience, adaptability and transformability in social-ecological systems. Ecology and Society 9(2): 5. [online] URL: http://www. ecologyandsociety.org/vol9/iss 2/art5/

Walters, C. 1997. Challenges in adaptive management of riparian and coastal ecosystems. Conservation Ecology 1(2): 1. [online] URL: http://www.consecol.org/vol1/iss2/art1/

Watts, D. J., and S. H. Strogatz. 1998. Collective dynamics of 'small-world' networks. Nature 393(1):440-442.

Westley, F. R., O. Tjornbo, L. Schultz, P. Olsson, C. Folke, B. Crona, and Ö. Bodin. 2013. A theory of transformative agency in linked social-ecological systems. Ecology and Society 18(3): 27. http://dx.doi.org/10.5751/ES-05072-180327 